\title{
Integrated Thematic Oriented "Pop Up Book" Development on Thematic Learning for Lower Grade Elementary School
}

\section{Sri Rahayu ${ }^{1 *}$, Arief Rahman Hakim², Palupi Dwi Yuliana ${ }^{3}$, Iskandar Ladamay ${ }^{4}$}

\author{
1,2,3,4 Elementary School Teacher Education Study Program, Universitas PGRI Kanjuruhan Malang, Malang, Indonesia
}

\section{ART ICLE IN F O}

\section{Article history:}

Received October 22, 2021

Revised October 24, 2021

Accepted November 11, 202

Available online November 25, 2021

Kata Kunci:

Buku Pop-Up, Tematik Integratif

Keywords:

Pop-Up Book, Integrative Thematic

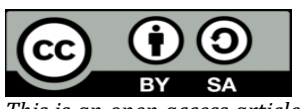

This is an open access article under the $\underline{\mathrm{CC}}$ BY-SA license.

Copyright (C) 2021 by Author. Published by Universitas Pendidikan Ganesha.

\begin{abstract}
A B S T RA K
Kurangnya penggunaan media pembelajaran khususnya pada pembelajaran tematik menyebabkan siswa kesulitan dalam belajar. Perlunya pengembangan media pembelajaran pada pembelajaran tematik untuk memudahkan siswa dalam beajar. Penelitian ini bertujuan untuk mengembangkan media Pop-Up Book dan mengetahui kelayakan serta kepraktisan media pembelajaran Pop-Up Book berbasis tematik integratif pada pembelajaran tematik Tema 8 Keselamatan di Rumah dan di Perjalanan. Jenis penelitian ini yaitu pengembangan. Metode penelitian yang digunakan adalah model ADDIE. Subjek penelitian ini terdiri dari validator ahli media pembelajaran, validator ahli isi, guru kelas, dan siswa. Instrumen pengumpulan data yang digunakan dalam penelitian ini adalah kuesioner dan expert judgement. Analisis data yang digunakan dalam penelitian ini adalah analisis kelayakan dan analisis kepraktisan. Teknik analisis data yang digunakan adalah analisis deskriptif kualitatif dan kuantitatif. Hasil penelitian menunjukkan bahwa media pembelajaran ini telah melalui tahapan-tahapan sistematis penelitian pengembangan. Berdasarkan hasil validasi para ahli materi, ahli media, praktisi, dan siswa menyimpulkan bahwa kualitas Pop-Up Book yang dikembangkan sangat baik. Pengembangan media pembelajaran Pop-Up Book layak, praktis dan menarik digunakan sebagai media pembelajaran pada pembelajaran tematik Kelas 2. Media Pop-Up Book dapat memudahkan siswa dalam belajar sehingga berdampak pada hasil belajar siswa yang meningkat.
\end{abstract}

\begin{abstract}
A B S T R A C T
The lack of use of learning media, especially in thematic learning, causes students to experience difficulties in learning. The need for learning media development in thematic learning to facilitate students in learning. This study aims to develop Pop-Up Book media and find the location and practicality of Pop-Up Book learning media based on integrative thematic learning on Theme 8 Safety at Home and Travel. This type of research is development. The research method used is the ADDIE model. This study consisted of expert validators of learning media, content expert validators, class teachers, and students. The data collection instruments used in this study were questionnaires and expert judgment. The data used in this study is a feasibility analysis and practicality analysis. The data analysis technique used is descriptive qualitative and quantitative analysis. The study results indicate that this learning media has gone through systematic stages of development research. Based on the validation of material experts, media experts, practitioners, and students, the Pop-Up Book's quality was very good. The Pop-Up Book learning media development is feasible, practical, and attractive to be used as a learning medium in Class 2 thematic learning. The Pop-Up Book media can facilitate students in learning so that it impacts increasing student learning outcomes.
\end{abstract}

\section{INTRODUCTION}

In the 21st century, all this information is accessible through advanced technology. The characteristic of the 21st century is that science and technology are increasingly intertwined (Eugenia et al., 2013; Husain \& Kaharu, 2021; Lavi et al., 2021). Developments in the 21st century utilize technology and communication in every life. Education in the 21st century also aims to realize the ideals of a prosperous and happy nation. 21st-century learning forms quality students, namely individuals who are independent, willing, and able to realize the ideals of their nation (Chalkiadaki, 2018; Husain \& Kaharu, 2021). 21stcentury learning emphasizes students' ability to seek information from various sources to formulate problems, think analytically, and collaborate and collaborate in solving problems (Haviz et al., 2020; Junedi et al., 2020; Nithyanantham et al., 2019). The Ministry of Education and Culture has adapted three 21st century education concepts to develop the curriculum to achieve this goal. The three concepts are 21stcentury skills, scientific approach, authentic learning, and authentic assessment adapted to develop education towards Creative Indonesia in 2045 (Husain \& Kaharu, 2021; Junedi et al., 2020; Luciana, 2020). The 2013 curriculum also emphasizes this concept. 
Learning in the 2013 curriculum applies a thematic approach. Submission of material is based on specific themes and integrated with other subjects that discuss similar themes or topics (Ningsih \& Maulida, 2019; Nugraha et al., 2017; Zulkifli, 2018). This thematic approach also emphasizes the character education of students. Based on the observations made, the 2013 curriculum was implemented from the start. However, learning media for thematic learning has not been found to support the learning process (Herawati et al., 2018; Kurnia et al., 2019a; Mediatati \& Suryaningsih, 2017). During the learning process, teachers only use student textbooks and teacher books already available (Kurnia et al., 2019b; Suantara et al., 2019). Teachers often use learning media for specific topics and are not integrated with the content of thematic learning lessons. One of the challenges often faced by teachers is the lack of attractive learning media for thematic learning to stimulate students' active participation and creative thinking skills (R. Karisma et al., 2019; Ulfah, 2019; Wardani \& Syofyan, 2018). Without representative learning media, students find it challenging to ask questions when they only read and see pictures in textbooks (Novika Auliyana et al., 2018; Yuliani et al., 2020). In addition, it makes them less enthusiastic in learning when textbooks only provide long descriptions without a single picture to present (Ma'ratusholihah et al., 2019; Riwanti \& Hidayati, 2019). Therefore, it is essential to use and integrate appropriate and exciting learning media during the learning process.

Learning media acts as an instrument to support teachers in delivering learning content (Dewi \& Budia, 2018). In addition, learning media plays a role in helping teachers visualize certain concepts based on real-life contexts so that students understand well what they are learning in class (Batubara, 2015; Fisnani et al., 2020; Ma'ratusholihah et al., 2019). Learning media has benefits in the learning process. Namely, it can clarify the presentation of messages and information so that it can facilitate and improve learning processes and outcomes, directs in stimulating students' thoughts, feelings so that they can increase children's learning motivation, and can overcome the limitations of senses, space, and time (Cabaleiro-Cerviño \& Vera, 2020; Dewi et al., 2019; Rofiq et al., 2019). It is very much needed for thematic learning. Integrative thematic learning is a learning approach that integrates various competencies from various subjects into various themes (Diputra, 2016; Hidayah, 2015; Nugroho \& Iqbal Arrosyad, 2020). One media that can increase students' enthusiasm for learning is pop-up book media. Pop Up adds a whole new dimension to a book, greeting card, or Box (Anggraini et al., 2019; Sari, 2017). Pop Up Box is a threedimensional display that contains interesting interactive elements that can move when opened as if an object appears from each opening in the form of a box or Box (Arum \& Yuanta, 2019; Sholeh, 2019). Pop Up Box in its manufacture using paper and folding techniques. Therefore, the Pop Up Box media can give an interesting impression to the readers, thus the message to be conveyed according to the learning objectives.

The findings of previous studies also stated that pop-up book media could increase students' enthusiasm for learning (Ningtiyas et al., 2019; Yuliani et al., 2020). Other research findings also state that the pop-up book media makes it easier for students to learn (Indrianto \& Kurniawati, 2020; Masturah et al., 2018). In addition to providing unique visualizations, Pop-Up Books can also stimulate students in learning, develop capacity, and make it easier for students to understand the learning content (Ruiz et al., 2014; Sari, 2017). Based on the description above, the researchers are interested in developing Pop-Up Book learning media based on integrative thematic learning for lower grade elementary schools. Researchers developed Pop-Up Book learning media about thematic learning because this media is enjoyable to use in thematic learning with a range of three teaching materials incorporated in themes close to students' daily lives. This research aims to develop Pop-Up Book learning media and determine the feasibility and practicality of PopUp Book learning media. It is hoped that this media can make it easier for students to learn.

\section{METHOD}

This research used research and development methods. The development model that researchers use in this study was the ADDIE development model. The steps of the development research model in this study consisted of analysis, design, development, implementation, and evaluation. This research was conducted at SDN 2 Banjararum Singosari, Malang Regency. The subjects of this study consisted of instructional media expert validators, content expert validators, second grade teachers of SDN 2 Banjararum, and second grade students of SDN Banjararum. The data collection instruments used in this study were questionnaires and expert judgement. Here in this phase, document analysis was done to analyse of student characteristic and teacher need analyse on thematic learning of second grade student to get the topic for materials. First step in this stage developed the design. The design developed based on thematic learning literature on Theme 8 Sub-Theme 2 Learning 6 of second grade elementary school. The content of Pop-Up Book according to material indicators. Second step in this stage the design prepared using graphic application to adjust the visual appearance. After designing based on thematic learning literature on Theme 8 Sub-Theme 2 Learning 6 of second grade elementary school, researcher developed them all 
become printed materials. Validation test was carried to determine the lack of Pop-Up Book that was developed. Then, researcher make revisions the product according the result of assessment from validator. After the Pop-Up Book proper to use, researcher implement the product and make trials with students grade 2. Rearcher also distributed the evaluation test for students to determine the level of their understanding after learning using Pop-Up Book media. Evaluation activity is to determine of achievement the learning media Pop-Up Book that was developed.

Questionnaire and expert judgement are instrument to collecting the data for this research. Questionnaire was use to collect data about the feasibility and practicality of Pop-Up Book media. This questionnaire was developed based on the theories of literature. Questionnaire was distributed to the media expert, material expert, practitionaire, and students. Expert judgement was used to collect data about the quality of Pop-Up Book media. There are two expert involved in this study. Validation media and content was conducted in the development step. Data analysis was used in this research are feasibility analysis and practicality analysis (Khoiriyah \& Sari, 2018; Kumalasari, 2018). The grid instruments are presented in Table 1, Table 2, and Table 3. The technique used to analyze the data is descriptive qualitative and quantitative analysis.

Table 1. Content Assessment Questionnaire

\begin{tabular}{lll}
\hline No & Aspect & Indicator \\
\hline 1. & Presentation & The accuracy of the material with KD and indicators \\
& & Clarity of material \\
& Truth of material & Coverage of material \\
& & Clarity of use instructions \\
& Learning & Clarity in language use \\
& Submission of interesting material \\
& Submission of coherent material \\
& Interesting for students \\
& Quality of delivery of material \\
& Image compatibility \\
& Color match \\
& Font match \\
\hline
\end{tabular}

Tabel 2. Media Assessment Questionnaire

\begin{tabular}{cl}
\hline Aspect & Indicator \\
\hline & The balance of the composition and layout of the writing on the \\
cover & The accuracy of the color of the title with the background \\
& Clarity of use instructions \\
& The accuracy of the paper size \\
& Accuracy in font size \\
& Ease of letters to read \\
& Font color accuracy \\
& Color compatibility with student characteristics \\
Development Learning Media & Attractive colors used \\
Pop Up Book & Language clarity \\
& The accuracy of language style \\
& Interesting storyline \\
& Picture quality \\
Image neatness & The suitability of the image to clarify the material \\
& The victory of the media \\
Media is relevant to the material \\
Quality of ingredients
\end{tabular}

Table 3. Practitionaire Assessment Questionnaire

\begin{tabular}{cl}
\hline Aspect & Indicator \\
\hline $\begin{array}{c}\text { Pop-Up Book Instructional Media } \\
\text { Development }\end{array}$ & The balance of the composition and layout of the writing on the cover \\
The accuracy of the color of the title with the background \\
Clarity of use instructions
\end{tabular}




\begin{tabular}{ll}
\hline Aspect & Indicator \\
\hline & The accuracy of the paper size \\
& Accuracy in font size \\
& Ease of letters to read \\
& Font color accuracy \\
& Color compatibility with student characteristics \\
& Attractive colors used \\
& Language clarity \\
& The accuracy of language style \\
& Interesting storyline \\
& Picture quality \\
& Image neatness \\
& The suitability of the image to clarify the material \\
& The victory of the media \\
& Media is relevant to the material \\
& Quality of ingredients \\
& The accuracy of the material with KD and indicators \\
& Clarity of material \\
& Truth of material \\
& Coverage of material \\
& Clarity of use instructions \\
& Clarity in language use \\
Submission of interesting material & Submission of coherent material \\
Presentation & Interesting for students \\
& Quality of delivery of material \\
Image compatibility \\
Color match \\
Font match \\
\hline Learning
\end{tabular}

\section{RESULT AND DISCUSSION}

\section{Result}

The content of Pop-Up Book developed according to the material indicators of Theme 8 Sub-Theme 2 Learning 6 second grade elementary school. This learning media is books with pictures that can standing and can be used directly by students with the guidance of the teacher. The media is designed using art papper as the main material of the book and print out images that are arranged to adapt the learning of Safety Themes at Home and Travel with basic competencies and indicators. The mapping of the basic competencies and indicators used in Pop-Up Book Media can be seen in the Table 4.

Table 4. The Data Mapping of Basic Competencies in the Pop-Up Book Media

\begin{tabular}{ll}
\hline \multicolumn{1}{c}{ Basic Competencies } \\
\hline $3.4 \quad \begin{array}{l}\text { Understanding the meaning of } \\
\text { being united in diversity in } \\
\text { schools. } \\
\text { Telling experiences of carrying } \\
\text { out activities that reflect unity } \\
\text { in diversity in schools. }\end{array}$
\end{tabular}

3.10 Pay close attention to the use of capital letters (God's name, person's name, religion's name) as well as full stops and question marks in the correct sentence.

4.10 Writing the text using capital letters (God's name, religious name, people's name), as well as

\section{Civic Education \\ 3.4.1. Giving examples of play activities that properly demonstrate unity in diversity of schoolmates.}

4.4.1. Simulate the experience of doing play activities that confidently reflect unity in diversity with schoolmates.

\section{Indonesian}

3.10.1. Reading simple sentences that contain rules for using question marks with proper pronunciation and intonation.

3.10.2. Finds the correct usage of question marks in sentences that have been read correctly.

4.10.1. Writing sentences by paying attention to the rules for using question marks correctly.

4.10.2. Editing sentences according to the correctness of the rules for using question marks correctly. 


\begin{tabular}{|c|c|c|}
\hline & Basic Competencies & Indikators of Competencies Achievement \\
\hline & $\begin{array}{l}\text { a full stop and question mark at } \\
\text { the end of a sentence. }\end{array}$ & $\begin{array}{l}\text { 4.10.3. Fixing short edited text according to the rules for } \\
\text { using question marks correctly. } \\
\text { Mathematic }\end{array}$ \\
\hline 3.6 & $\begin{array}{l}\text { Describe and determine length } \\
\text { (including distance), weight, } \\
\text { and time in standard units, } \\
\text { related to everyday life. }\end{array}$ & 3.6.1. Correctly specify the time unit conversion. \\
\hline 4.6 & $\begin{array}{l}\text { Take measurements of length } \\
\text { (including distance), weight, } \\
\text { and time in standard units, } \\
\text { related to everyday life. }\end{array}$ & Correctly state the duration of the activity in hours. \\
\hline
\end{tabular}

Pop-Up Book media is a book with $24 \mathrm{~cm} \times 32 \mathrm{~cm}$ the size and when opened is A3+. The function is to practicality media when carried anywhere without taking up space, because the size is the same with books in general. Here is a look of Pop-Up Book learning media can be seen in the Figure 1.

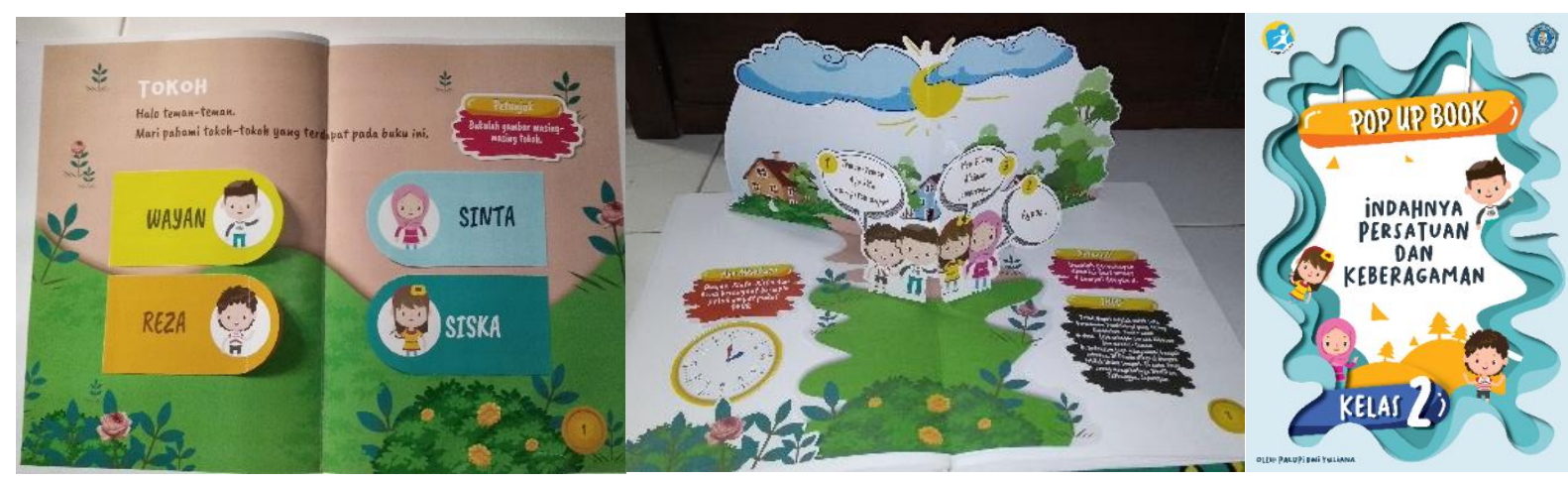

Figure 1. The Look of Pop-Up Book Learning Media

The quality of Pop-Up Book media for second grade elementary school was quantified and the mean score of the data was classified based on the following criteria that were adopted from (Khoiriyah \& Sari, 2018; Kumalasari, 2018). Based on the results of the assessment of material experts and media experts, it is stated that the Pop-Up Book media that has been developed is in the very feasible category, it can be seen from the results of the material expert's assessment that a percentage of $85 \%$ is included in the very high feasibility category and the results of the assessment from media experts. 93\% is in the very high eligibility category. After the Pop-Up Book media was validated to material experts and media experts, the Pop-Up Book media was implemented and tested in grade II student of SDN 2 Banjararum Singosari, Malang City. The results of the teacher's assessment as a practitioner. Based on the results of the teacher's assessment as a practitioner, the results show that the Pop-Up Book media is a very practical category to be implemented in integrated thematic learning for low grade elementary school students. While the results of student assessments of Pop-Up Book media are very attractive and easy to use by low-grade students, it is illustrated by the results of the teacher's questionnaire $88.7 \%$ and students $98.27 \%$.

\section{Discussion}

Based on the results of the assessment of material experts and media experts, the Pop-Up Book media that has been developed is in the very feasible category. The role of media in learning process actually is very important. Media can support the learning process, make it easier for students understanding as well as improve the quality and will impact on the quality of student learning outcomes. Pop-Up Book is a book which has movable parts or has 3 dimensional elements as well provide an interesting story visualization, starting form the image can move when the page is opened (Baiduri et al., 2019; Diyantari et al., 2020). Visually 3D media has several function namely have attention function to attract students attention, the affective function which is visible from student enjoyment when studying or reading, and the counterproductive function is to provide context to help students understand the content of the reading (Alviolita \& Huda, 2019; Septian \& Tampubolon, 2015; Yuliani et al., 2020). Utility of Pop-Up Book media are to develop childrens love to reading book, can be useful for critical thinking and develop creativity, can catch on the meaning through the representation of attractive images and for generate desire and motivate to read (Kusmariyatni, 2020; Nikmah et al., 2019). Pop-Up Book are made by giving surprise on each page 
so that it can give a sense for reader when opening every page. The surprises on each page will also make readers feel curious to open one book page to the next (T. W. Ningtiyas et al., 2019; Ruqoyyah et al., 2020). The colors used in the Pop-Up Book media that have been developed have an psychology influence of humans (Setyohadi, 2010). Pop-Up Book media is appropriate and feasible to used (Mustika \& Ain, 2020; Putri et al., 2019).

Use of Pop-Up Book media make learning activities more meaningful and interesting for students (Hidayah et al., 2020; Maharani et al., 2018). In accordance with the results of the research assessment, when the learning takes place, the media of Pop-Up Book attracts the attention of students. So, students can focus on the learning content presented (Karisma et al., 2020; Masturah et al., 2018). In addition, the presence of this instructional media support teacher to convey the content in thematic learning. With an attractive form of media, it facilitate teachers to create an attractive learning activities which encourage students' attention during the learning process. So it is very important for the principal to make policies related to the importance of using varied learning methods and supported by relevant media to improve student learning achievement (Rahayu et al., 2019; Sholeh, 2019). The development of learning media PopUp Book can be developed in a sustainable manner with different material and during the learning process using media Pop-Up Book, edacutors must better control the class (Anggraini et al., 2019).

Use learning media based on Pop-Up Book is effective to improve student achievement and effective to improve cognitive ability for children (Elisa Diah Masturah et al., 2018; Rahmawati \& Rukiyati, 2018). The content in the media is well conveyed (Rusman, 2017). Pop-Up Book media also have motion elements so that the image or story is shown to be more interesting (Ruiz et al., 2015). The advantage of Pop-Up Book media was developed is gived a concrete impression in the learning process, involving students to be active while learning, so the material could remembered longer and learning becomes more meaningful (Safri et al., 2017). This is in accordance with the statement that learning media can be used in activities to convey and present information or learning content (P. K. Dewi \& Budia, 2018; Indrianto \& Kurniawati, 2020).

\section{CONCLUSION}

The results of research on the development of Pop-Up Book media are in the very feasible category. Meanwhile, the results of the teacher's assessment as practitioners show that the Pop-Up Book media is a very practical category to be implemented in integrated thematic learning for low grade elementary school students. While the results of student assessments of Pop-Up Book media are very attractive and easy to use by low-grade students..

\section{REFERENCES}

Alviolita, \& Huda. (2019). Media Pop Up Book Dalam Pembelajaran Bercerita. Jurnal Pendidikan Bahasa Indonesia, 7(1). https://doi.org/10.30659/j.7.1.49-57.

Anggraini, W., Nurwahidah, S., Asyhari, A., Reftyawati, D., \& Haka, N. B. (2019). Development of Pop-Up Book Integrated with Quranic Verses Learning Media on Temperature and Changes in Matter. Journal of Physics: Conference Series, 1155(1), 1-9. https://doi.org/10.1088/1742-6596/1155/1/012084.

Arum, R. A. S., \& Yuanta, F. (2019). Pengaruh Media Pop-Up Book Terhadap Hasil Belajar Siswa Sekolah Dasar Tema Indahnya Keragaman Di Negeriku. Prosiding Seminar Nasional Cendekiawan, 2. https://doi.org/10.25105/semnas.v0i0.5875.

Baiduri, Marhan, \& Lufita. (2019). Pengembangan media pembelajaran pop-up book berbasis audio pada materi bangun datar segiempat. Jurnal Program Studi Pendidikan Matematika, 8(1). https://doi.org/10.24127/ajpm.v8i1.1951.

Batubara, H. H. (2015). Pengembangan Media Pembelajaran Interaktif pada Materi Operasi Bilangan Bulat. Jurnal Madrasah Ibtidaiyah, 1(1), 1-12.

Cabaleiro-Cerviño, G., \& Vera, C. (2020). The Impact of Educational Technologies in Higher Education. GIST - Education and Learning Research Journal, 20,155-169. https://doi.org/10.26817/16925777.711.

Chalkiadaki, A. (2018). A systematic literature review of 21st century skills and competencies in primary education. International Journal of Instruction, 11(3), 1-16. https://doi.org/10.12973/iji.2018.1131a.

Dewi, I. G. A. A. S. S., Sudatha, I. G. W., \& Sukmana, A. I. W. I. Y. (2019). Pengembangan Multimedia Pembelajaran Interaktif Berorientasi Pendidikan Karakter Mata Pelajaran Bahasa Bali. Journal of Education Technology, 3(3), 190. https://doi.org/10.23887/jet.v3i3.21745.

Dewi, P. K., \& Budia, N. (2018). Media Pembelajaran Bahasa: Aplikasi Teori Belajar dan Strategi Pengoptimalan Pembelajaran. UB-Press. 
Diputra, K. S. (2016). Pengembangan Multimedia Pembelajaran Tematik Integratif Untuk Siswa Kelas Iv Sekolah Dasar. JPI (Jurnal Pendidikan Indonesia), 5(2), 125. https://doi.org/10.23887/jpiundiksha.v5i2.8475.

Diyantari, I. A. K. D., Wiyasa, N., \& Manuaba, S. (2020). Model Snowball Throwing Berbantuan Media Pop Up Book Berpengaruh Terhadap Kompetensi Pengetahuan Ipa. Jurnal Ilmiah Pendidikan Profesi Guru, 3(1), 9-21. https://doi.org/10.23887/jippg.v3i1.26973.

Eugenia, Raymond, \& Leung, W. N. (2013). Ready for 21st-century Education - Pre-service Music Teachers Embracing ICT to Foster Student-centered Learning. Procedia - Social and Behavioral Sciences, 73. https://doi.org/10.1016/j.sbspro.2013.02.047.

Fisnani, Y., Utanto, Y., \& Ahmadi, F. (2020). The Development of E-Module for Batik Local Content in Pekalongan Elementary School. Innovative Journal of Curriculum and Educational Technology, 9(1), 40-47. https://doi.org/10.15294/IJCET.V9I1.35592.

Haviz, M., Lufri, L., \& Maris, I. M. (2020). Assessing prospective biology teachers (PBTs) perceptions on thinking as a 21st century skill: A case study at Islamic University. Jurnal Pendidikan IPA Indonesia, 9(3), 319-329. https://doi.org/10.15294/jpii.v9i3.24077.

Herawati, A., Wahyudi, W., \& Indarini, E. (2018). Pengembangan Media Pembelajaran Bangun Ruang Berbasis Discovery Learning dengan Construct 2 dalam Meningkatkan Kemampuan Pemecahan Masalah Matematika. Jurnal Ilmiah Sekolah Dasar, 2(4), 396. https://doi.org/10.23887/jisd.v2i4.16157.

Hidayah, N. (2015). Pembelajaran Tematik Integratif di Sekolah Dasar. Jurnal Pendidikan Dan Pembelajaran Dasar, 2(1), 34-49.

Hidayah, N., Wahyuni, R., \& Hasnanto, A. T. (2020). Pengembangan Media Pembelajaran Gambar Berseri Berbasis Pop-Up Book Untuk Meningkatkan Keterampilan Menulis Narasi Bahasa Indonesia. Jurnal Pendidikan Dan Pembelajaran Dasar, 7(1). https://doi.org/10.24042/terampil.v7i1.6182.

Husain, R., \& Kaharu, A. (2021). Menghadapi Era Abad 21: Tantangan Guru Pendidikan Anak Usia Dini di Kabupaten Bone Bolango. Jurnal Obsesi: Jurnal Pendidikan Anak Usia Dini, 5(1), 85-92. https://doi.org/10.31004/obsesi.v5i1.527.

Indrianto, N., \& Kurniawati. (2020). Developing Pop-Up Book Based Media To Improve The First Grader Students' Learning Achievement on The Theme of Natural Event of Min 4 Jember. Jurnal Pendidikan Dasar Nusantara, 5(2), 279-291. https://doi.org/10.29407/jpdn.v5i2.13836.

Junedi, B., Mahuda, I., \& Kusuma, J. W. (2020). Optimalisasi keterampilan pembelajaran abad 21 dalam proses pembelajaran pada Guru MTs Massaratul Mut'allimin Banten. Transformasi: Jurnal Pengabdian Masyarakat, 16(1), 63-72. https://doi.org/10.20414/transformasi.v16i1.1963.

Karisma, I. K. E., Margunayasa, I. G., \& Prasasti, P. A. T. (2020). Media Pop-Up Book pada Topik Perkembangbiakan Tumbuhan dan Hewan Kelas VI Sekolah Dasar. Jurnal Ilmiah Sekolah Dasar, 4(2), 121-130. https://doi.org/10.23887/jisd.v4i2.24458.

Karisma, R., Mudzanatun, \& Prasena. (2019). Pengembangan Media Audio Visual untuk Mendukung Pembelajaran Tematik Tema 7 Subtema 2. Jurnal Penelitian Dan Pengembangan Pendidikan, 3(3). https: //doi.org/10.23887/jppp.v3i3.19255.

Khoiriyah, E., \& Sari, E. Y. (2018). Pengembangan Media Pembelajaran Pop-Up Book Pada Mata Pelajaran IPA Kelas III SDN 3 Junjung Kecamatan Sumbergempol Kabupaten Tulungagung Tahun Ajaran 2017/2018. Jurnal Bidang Pendidikan Dasar (JBPD), 2(2), 22-32.

Kumalasari, M. P. (2018). Kepraktisan Penggunaan Multimedia Interaktif pada Pembelajaran Tematik Kelas IV SD. Jurnal Bidang Pendidikan Dasar (JBPD), 2(1), 1-11.

Kurnia, Damayani, \& Kiswoyo. (2019a). Keefektifan Model Pembelajaran Number Head Together (NHT) Berbantu Media Puzzle Terhadap Hasil Belajar Matematika. Jurnal Ilmiah Sekolah Dasar, 3(2), 192. https://doi.org/10.23887/jisd.v3i2.17772.

Kurnia, V. T., Damayani, A. T., \& Kiswoyo, K. (2019b). Keefektifan Model Pembelajaran Number Head Together (NHT) Berbantu Media Puzzle Terhadap Hasil Belajar Matematika. Jurnal Ilmiah Sekolah Dasar, 3(2), 192. https://doi.org/10.23887/jisd.v3i2.17772.

Kusmariyatni, N. (2020). Media Pop-Up Book pada Topik Sistem Tata Surya Kelas VI Sekolah Dasar. Jurnal Ilmiah Sekolah Dasar, 4(2), 197-208. https://doi.org/10.23887/jisd.v4i2.25135.

Lavi, R., Tal, M., \& Dori, Y. J. (2021). Perceptions of STEM alumni and students on developing 21st century skills through methods of teaching and learning. Studies in Educational Evaluation, 70, 1-11. https://doi.org/10.1016/j.stueduc.2021.101002.

Luciana, N. L. R. (2020). Teachers' Readiness in Inserting the 21st Century Skills in the Lesson Plan in Teaching English. Jurnal Pendidikan Dan Pengajaran, 53(2), 168. https://doi.org/10.23887/jpp.v53i2.26406.

Ma'ratusholihah, Priyanto, \& Damayani, A. . (2019). Pengembangan media pembelajaran tematik ular 
tangga berbagai pekerjaan. Mimbar PGSD Undiksha, https://doi.org/10.23887/jjpgsd.v7i3.19411.

Maharani, H. R., Ubaidah, N., \& Aminudin, M. (2018). Efektifitas Model Concept Attainment Ber-Budaya Akademik Islami Berbantuan Pop-Up Book pada Materi Bangun Ruang Sisi Datar. Kreano: Jurnal Matematika Kreatif-Inovatif, 9(1), 100-106. https://doi.org/10.15294/kreano.v9i1.12693.

Masturah, E D, Mahadewi, L. P. P., \& Simamora. (2018). Pengembangan Media Pembelajaran Pop-Up Book pada Mata Pelajaran IPA Kelas III Sekolah Dasar. Jurnal EDUTECH ..., 6(2), 212-221. https://doi.org/10.23887/jeu.v6i2.20294.

Masturah, Elisa Diah, Mahadewi, L. P. P., \& Simamora, A. H. (2018). Pengembangan Media Pembelajaran Pop-Up Book pada Mata Pelajaran IPA Kelas III Sekolah Dasar. Jurnal EDUTECH Universitas Pendidikan Ganesha, 6(2), 212-221. https://doi.org/10.23887/jeu.v6i2.20294.

Mediatati, N., \& Suryaningsih, I. (2017). Penggunaan Model Pembelajaran Course Review Horay Dengan Media Flipchart Sebagai Upaya Meningkatkan Hasil Belajar PKn. Jurnal Ilmiah Sekolah Dasar, 1(2). https://doi.org/10.23887/jisd.v1i2.10146.

Mustika, D., \& Ain, S. Q. (2020). Peningkatan Kreativitas Mahasiswa Menggunakan Model Project Based Learning dalam Pembuatan Media IPA Berbentuk Pop Up Book. Jurnal Basicedu, 4(4), 1167-1175. https://doi.org/10.31004/basicedu.v4i4.518.

Nikmah, S., Nuroso, H., \& Reffiane, F. (2019). Pengaruh Model Pembelajaran Terpadu Tipe Shared Berbantu Media Pop- Up Book Terhadap Hasil Belajar. Jurnal Pedagogi Dan Pembelajaran, 2(2), 264. https://doi.org/10.23887/jp2.v2i2.17920.

Ningsih, D. P., \& Maulida, I. (2019). Implementasi Kurikulum 2013 Dalam Membentuk Karakter Siswa Pada Pembelajaran Tematik Integratif Kelas IV di SDN I Gapuk. Jurnal Pendidikan, 3(1). https: //doi.org/10.36312/jisip.v3i1.988.

Ningtiyas, T., Setyosari, P., \& Praherdiono, H. (2019). Pengembangan Media Pop-Up Book Untuk Mata Pelajaran Ipa Bab Siklus Air Dan Peristiwa Alam Sebagai Penguatan Kognitif Siswa. Jurnal Kajian Teknologi Pendidikan, 2(2), 115-120. https://doi.org/10.17977/um038v2i22019p115.

Ningtiyas, T. W., Setyosari, P., \& Praherdiono, H. (2019). Pengembangan Media Pop-Up Book untuk Mata Pelajaran IPA Bab Siklus Air dan Peristiwa Alam sebagai Penguatan Kognitif Siswa. Jurnal Kajian Teknologi Pendidikan, 2(2), 115-120. https://doi.org/10.17977/um038v2i22019p115.

Nithyanantham, V., Paulmony, R., \& Ramadan H., S. (2019). Self-Perspective of 21st Century Educators: A Challenge in The Globalised Educational World. International Journal of Educational Research Review, 4(3). https://doi.org/10.24331/ijere.573869.

Novika Auliyana, S., Akbar, S., \& Yuniastuti. (2018). Penerapan Pembelajaran Tematik Terpadu di Sekolah Dasar. Jurnal Pendidikan: Teori, Penelitian, Dan Pengembangan, 3(12), 1572-1582. https://doi.org/10.17977/jptpp.v3i12.11796.

Nugraha, R., Purnamasari, I., \& Baedowi, S. (2017). Evaluasi Penerapan Standar Penilaian Kurikulum 2013 Pada Kelas 4 Sekolah Dasar Di Kecamatan Jambu. Jurnal Sekolah, 2(1), 94. https://doi.org/10.24114/js.v2i1.9925.

Nugroho, F., \& Iqbal Arrosyad, M. (2020). Moodle Multimedia Development in Web-based Integrative Thematic Learning for Class IV Elementary Students. Cendekiawan, 2(1), 49-63. https://doi.org/10.35438/cendekiawan.v2i1.177.

Putri, Q. K., Pratjojo, P., \& Wijayanti, A. (2019). Pengembangan Media Buku Pop-Up untuk Meningkatkan Kemampuan Menyimak Tema Menyayangi Tumbuhan dan Hewan di Sekitar. Jurnal Pedagogi Dan Pembelajaran, 2(2), 169. https://doi.org/10.23887/jp2.v2i2.17905.

Rahayu, S., Rahayunita, C. I., \& Ladamay, I. (2019). Improving Basic School Students Capabilities In Doing Distribution Operations Through Combination of Media Construction and Group Investigation (GI). 1st International Science, Technology, Engineering, and Mathematic Learning Forum, 683-691.

Rahmawati, D. I., \& Rukiyati, R. (2018). Developing Pop-Up Book Learning Media to Improve Cognitive Ability of Children. 4th International Conference on Early Chilhood Education, 249(Secret), 60-69. https://doi.org/10.2991/secret-18.2018.10.

Riwanti, R., \& Hidayati, A. (2019). Pengembangan Modul Pembelajaran Tematik Berbasis Pendidikan Karakter Di Kelas V Sekolah Dasar. Jurnal Basicedu, 3(2), 572-581. https://doi.org/10.31004/basicedu.v3i2.41.

Rofiq, A., Mahadewi, L. P. P., \& Parmiti, D. P. (2019). Pengembangan Multimedia Pembelajaran Interaktif Pada Mata Pelajaran Ips Terpadu. Journal of Education Technology, 3(3), 126. https://doi.org/10.23887/jet.v3i3.21732.

Ruiz, C. R., Le, S. N., \& Low, K.-L. (2015). Generating Animated Paper Pop-Ups from the Motion of Articulated Characters. Visual Computer, 31(6), 925-935.

Ruiz, C. R., Le, S. N., Yu., J., \& Low, K.-L. (2014). Multi-Style Paper Pop-Up Designs from 3D Models. Journal 
Eurograpihics, 33(2), 487-496. https://doi.org/10.1111/cgf.12320.

Ruqoyyah, R., Fatkhurrohman, M. A., \& Arfiani, Y. (2020). Implementasi Model Inkuiri Terbimbing Berbantuan Pop-up book untuk Meningkatkan Kemampuan Berpikir Kreatif Peserta Didik. JEMS: Jurnal Edukasi Matematika Dan Sains, 8(1), 42-48. https://doi.org/10.25273/jems.v8i1.6166.

Rusman. (2017). Belajar dan Pembelajaran Berorientasi Standar Proses Pendidikan. Kencana.

Safri, M., Sari, S. A., \& Marlina. (2017). Pengembangan Media Belajar Pop-Up Book Pada Materi Minyak Bumi. Jurnal Pendidikan Sains Indonesia (Indonesian Journal of Science Education), 5(1), 107-113.

Sari, S. A. (2017). The Development of Pop-up Book on the Role of Buffer in the Living Body. European Journal of Social Sciences Education and Research, 10(2), 12-23. https://doi.org/10.26417/ejser.v10i2.p213-221.

Septian, A., \& Tampubolon, J. (2015). Pengaruh Pembelajaran Menggunakan Media Tiga Dimensi (3D) Terhadap Hasil Belajar Menggambar Dengan Perangkat Lunak Kelas XI Program Keahlian Teknik Gambar Bangunan Smk Negeri 2 Meulaboh. Educational Building, 1(1), 70-78. https://doi.org/10.24114/eb.v1i1.2827.

Setyohadi, B. (2010). Pengaruh Warna Terhadap Kamar Tidur Anak. Jurnal Teknik Sipil Dan Perencanaan, 12(1), 79-90. https://doi.org/10.15294/jtsp.v12i1.7002.

Sholeh, M. (2019). Pengembangan Media Pop-Up Book Berbasis Budaya Lokal Keberagaman Budaya Bangsaku Siswa Kelas IV Sekolah Dasar. Jurnal Gentala Pendidikan Dasar, 4(1), 138-150. https://doi.org/10.22437/gentala.v4i1.6979.

Suantara, I. K. T., Ganing, N. N., Agung, I. G., \& Wulandari, A. (2019). Pengaruh Model Pembelajaran Think Pair Share Berbantuan Media TTS terhadap Kompetensi Pengetahuan IPA. Jurnal Ilmiah Sekolah Dasar, 3(4), 473-480. https://doi.org/10.23887/jisd.v3i4.21783.

Ulfah, A. (2019). Pengembangan Media Pembelajaran Kartik (Kartu Tematik) Tema 8 Keselamatan Di Rumah Dan Di Perjalanan Bagi Siswa Sekolah Dasar Kelas Ii. Profesi Pendidikan Dasar, 1(2), 211224. https://doi.org/10.23917/ppd.v1i2.9067.

Wardani, R. K., \& Syofyan, H. (2018). Pengembangan Video Interaktif pada Pembelajaran IPA Tematik Integratif Materi Peredaran Darah Manusia. Jurnal Ilmiah Sekolah Dasar, 2(4), 371. https://doi.org/10.23887/jisd.v2i4.16154.

Yuliani, F., Herman, \& Tarmizi, P. (2020). Pengaruh Model Discovery Learning Berbantuan Media Pop-Up Book terhadap Hasil Belajar Tematik Siswa Kelas IV SD Gugus X Kota Bengkulu. Jurnal Riset Pendidikan Dasar, 3(1), 1-8. https://doi.org/10.33369/juridikdas.3.1.1-8.

Zulkifli, M. (2018). Analisis Bentuk Evaluasi Kurikulum 2013 Mata Pelajaran Bahasa Arab di MI. AlMadrasah: Jurnal Pendidikan Madrasah Ibtidaiyah, 2(2), 125-143. https://doi.org/10.35931/am.v0i0.29. 